\title{
Axonal Transport of Synapsin I-like Proteins in Rabbit Retinal Ganglion Cells
}

\author{
Celia Baitingera and Mark Willard \\ Department of Anatomy and Neurobiology, Washington University School of Medicine, Saint Louis, Missouri 63110
}

\begin{abstract}
Synapsin I is a neuronal phosphoprotein that is associated with the cytoplasmic surface of small, clear synaptic vesicles in neuronal synaptic terminals; it may play an important role in synaptic transmission. In vitro, it can interact with fodrin, a relative of the erythrocyte protein spectrin. We have investigated the delivery of synapsin I from its site of synthesis in neuronal cell bodies to synaptic terminals by means of the process of axonal transport. We labeled the newly synthesized proteins of rabbit retinal ganglion cells by injecting ${ }^{35} S$-methionine into the vitreous humour, and subsequently observed the appearance of radioactive synapsin I (identified by its 2-dimensional electrophoretic mobility) in tissues containing the axons and synaptic terminals of these neurons. A portion of the newly synthesized synapsin I was axonally transported at the velocity of the most rapidly transported (group I) proteins, which comprise membrane-associated proteins and may include elements of synaptic vesicles. However, the subsequent time course of labeling of synapsin $I$ in the axons suggests that greater than $90 \%$ of the axonally transported synapsin I may comprise 2 additional populations - one transported rapidly, the other slowly-that are released from the cell bodies only after a delay of more than $1 \mathrm{~d}$. The delayed, slowly transported population moves at the velocity (approximately $6 \mathrm{~mm} / \mathrm{d}$ ) of groups III and IV (which include fodrin and other proteins of the membrane cytoskeleton). We consider whether such distinct populations may correspond to functionally specialized variants of synapsin I-like proteins that may be transported in association with different organelles. The electrophoretic mobility of labeled synapsiin 1-like proteins in the axons changed subtly with time. Additional subtle differences between labeled synapsin I-like proteins in the axons and the terminalcontaining tissues suggest that certain posttranslational modifications occur specifically in the terminals.
\end{abstract}

Synapsin I is a neuron-specific phosphoprotein that is most concentrated in nerve terminals, where it is located predominantly on the cytoplasmic surfaces of small $(40-60 \mathrm{~nm})$ synaptic

\footnotetext{
Received Jan. 29, 1987; Ievised May 14, 1987; accepted May 18, 1987.

This work was supported by NIH Grant EYO 2682, a McKnight Foundation award, and an NSF Predoctoral Fellowship to C.B. We thank R. Cheney and L. O'Leary for their comments on the manuscript, Drs. P. Skene and J. Levine for experimental advice, and C. Simon for technical assistance.

Correspondence should be addressed to Mark Willard, Department of Anatomy and Neurobiology, Washington School of Medicine, 660 South Euclid Avenue, Saint Louis, MO 63110.

a Present address: Department of Pharmacology, Stanford University School of Medicine, Stanford, CA 94305.

Copyright (C) 1987 Society for Neuroscience $0270-6474 / 87 / 113723-13 \$ 02.00 / 0$
}

vesicles (De Camilli et al., 1983a, b; Huttner et al., 1983; Navone et al., 1984). Synapsin I comprises 2 basic polypeptides (isoelectric point $>10$ ) with molecular weights of 86,000 (Ia) and 80,000 daltons (Ib) (Ueda and Greengard, 1977); each is phosphorylated at multiple sites by calcium/calmodulin-dependent and cAMP-dependent protein-kinases (Huttner and Greengard, 1979; Huttner et al., 1981). The phosphorylation state of synapsin I appears to be intimately related to the process of synaptic transmission (Krueger et al., 1977; Forn and Greengard, 1978; Strombom et al., 1979; Dolphin and Greengard, 1981; Nestler and Greengard, 1982a, b; Tsou and Greengard, 1982; Huttner et al., 1983; Llinas et al., 1985; Schiebler et al., 1986), indicating that synapsin I performs an important function in synaptic vesicle release. Recently, it has been reported that synapsin I can bind to the cytoskeletal spectrin-like proteins in a phosphorylation-sensitive manner (Baines and Bennett, 1985; Goodman, 1986; Krebs et al., 1986a), and that this binding enhances the binding of these spectrin-like proteins to F-actin (Krebs et al., 1986b). It has been noted that these properties could be important for the mechanism by which neurotransmitter is released (Krebs et al., 1986b). This interaction of synapsin I with spectrin-like proteins also raises the possibility that synapsin I-like proteins have functions in the cell in addition to those involved in synaptic vesicle metabolism.

To investigate the delivery of synapsin I to the axons and synaptic terminals, we labeled newly synthesized synapsin I with ${ }^{35} \mathrm{~S}$-methionine in the cell bodies of rabbit retinal ganglion cells, and observed the time course of appearance of labeled synapsin I in the tissues which contain the axons and synaptic terminals of these neurons. Most axonal and synaptic proteins are synthesized in the neuronal cell bodies, and conveyed to their destinations by the process of axonal transport (for a review, see Grafstein and Forman, 1980). In mammalian retinal ganglion cells, 5 groups of proteins, designated groups I-V, can be distinguished according to their maximum time-averaged velocities of transport (e.g., Willard et al., 1974; Willard and Hulebak, 1977). Most of the group I proteins (velocities in excess of 240 $\mathrm{mm} / \mathrm{d}$ ) are associated with membranes (e.g., Lorenz and Willard, 1978), and it is likely that constituents of synaptic vesicles may be included among these most rapidly transported proteins (Brimijoin and Wiermaa, 1977; Goldberg et al., 1978). Group II may represent, in part, the movement of mitochondria down the axon (Lorenz and Willard, 1978). A population of the protein fodrin (Levine and Willard, 1981), which is a relative of erythrocyte spectrin (Goodman et al., 1981; Bennett et al., 1982; Burridge et al., 1982; Glenney et al., 1982; Repasky et al., 1982; Cheney et al., 1983), moves at the velocity of group II (40-80 $\mathrm{mm} / \mathrm{d}$; Willard et al., 1974). Additional populations of fodrin move at the velocities of groups III and IV (2-8 mm/d) and 
group V (approximately $1 \mathrm{~mm} / \mathrm{d}$ ) (Levine and Willard, 1980; Cheney et al., 1983). Groups III and IV also include actin and myosin (Willard, 1977; Black and Lasek, 1979; Willard et al., 1979), calmodulin (Erickson et al., 1980; Brady et al., 1981), and many other proteins (Brady and Lasek, 1981; Garner and Lasek, 1981), whereas group $\mathrm{V}$ includes neurofilament proteins (Hoffman and Lasek, 1975; Willard and Hulebak, 1977). It has been considered that groups III and IV may represent in part the movement of the plasma membrane-associated cytoskeleton (Cheney et al., 1983), as well as an internal cytoskeletal matrix and associated proteins (Willard et al., 1979; Black and Lasek, 1980), whereas group V may represent the movement of the intcrnal cytoskeleton, composed of neurofilaments and associated proteins (Hoffman and Lasek, 1975).

The experiments reported here were undertaken to compare the axonal transport of synapsin I with these previously described transported proteins-especially with the membrane proteins of group I because of their potential relationship to synaptic vesicles, and with fodrin because of its potential for association with synapsin I. If synapsin I-like proteins became tightly associated with synaptic vesicles or fodrin shortly after they were synthesized, then this association should be reflected in their time courses of labeling in the axons and synaptic terminals. We observed that a population of synapsin I-like protein is rapidly transported at velocities comparable to those of previously identified group I polypeptides. In addition, the labeling of synapsin I-like protein increased with time in a manner suggesting the possibility that a major fraction of synapsin I-like protein is released from the cell body only after a delay of more than $1 \mathrm{~d}$, and that a population of this delayed synapsin $\mathrm{I}$ is transported more slowly, at velocities comparable to those of the proteins of groups III and IV.

\section{Materials and Methods}

Identification of synapsin I by endogenous phosphorylation in the presence of $C A M P$. Cylic-AMP-dependent phosphorylation of synapsin in a mitochondrial-synaptosomal subcellular fraction of rabbit brain designated M1 (de Robertis et al., 1967) was assayed by a modification of the method of Ueda and Greengard (1977). Aliquots (100 $\mu \mathrm{g}$ in a total volume of $110 \mu \mathrm{l}$ ) of the $\mathrm{M} 1$ fraction were preincubated for $30 \mathrm{sec}$ at $30^{\circ} \mathrm{C}$ in a solution containing HEPES (50 mM, pH 7.4), $\mathrm{MgCl}_{2}(10 \mathrm{~mm})$, isobutylmethylxanthine $(1 \mathrm{mM})$, and EGTA $(1 \mathrm{mM})$, in the presence or absence of cyclic AMP $(5 \mu \mathrm{M})$. The phosphorylation reaction was initiated by the addition of $7 \mu$ l of gamma- ${ }^{32} \mathrm{P}-\mathrm{ATP}$ (tetra[triethylammonium] salt (New England Nuclear, Boston, $\mathrm{MA} ; 8-25 \mathrm{Ci} / \mathrm{mmol}$ ) to produce a final concentration of 4-10 $\mu \mathrm{M}$; the mixture was incubated for $10 \mathrm{sec}$ at $30^{\circ} \mathrm{C}$. The reaction was terminated by the addition of $5 \mathrm{ml}$ of a solution containing TCA $(7 \% \mathrm{wt} / \mathrm{vol})$, ATP $(1 \mathrm{~mm})$, and $\mathrm{NaPO}_{4}(10$ mM) at approximately $4^{\circ} \mathrm{C}$. The protein was collected by centrifugation at $3000 \times g$ for $15 \mathrm{~min}$. The precipitate was washed 3 times with a solution of this same composition and once in $\mathrm{H}_{2} \mathrm{O}$ (approximately $4^{\circ} \mathrm{C}$ ). Each wash was followed by centrifugation. Phosphorylated polypeptides were analyzed by electrophoresis in one of the gel systems described below, followed by fluorography of the gel.

Labeling of retinal ganglion cells. Proteins in the cell bodies of rabbit retinal ganglion cells were radioactively labeled by injection of ${ }^{35} \mathrm{~S}$ methionine (Amersham, Arlington Heights, IL; approximately $1200 \mathrm{Ci}$ / mmol; $0.48-0.73 \mathrm{mCi}$ ) into the vitreous of a rabbit's left eye, which had been anesthetized by topical application of proparacaine hydrochloride $(0.5 \% \mathrm{wt} / \mathrm{vol})$. A volume of $40 \mu \mathrm{l}$ of the isotope was injected at the concentration supplied by the manufacturer. At various postlabeling intervals, animals were killed by injection of sodium pentobarbital into the marginal ear vein, and the segment $(12 \mathrm{~mm})$ of each optic nerve closest to the optic chiasm, the left and right optic tracts, extending to the level of the thalamus (the entire optic chiasm was included with the right optic tract, which contained the axons from the injected eye), the segment of tissue from the dorsal thalamus that contained the lateral geniculate nucleus as well as overlying white matter, and the left and right superior colliculi were removed and frozen on solid $\mathrm{CO}_{2}$.

Labeling of locally synthesized polypeptides of visual system tissues. For local labeling of visual system polypeptides, rabbits were anesthetized with chloral hydrate, the skull was surgically exposed, and 2 holes were drilled in the left side of the skull, one $5-6 \mathrm{~mm}$ from the midline suture and 2-4 $\mathrm{mm}$ posterior to the anterior edge of the orbit (for access to the optic tract and lateral geniculate nucleus), and the second 2-3 $\mathrm{mm}$ from the midline suture and 4-6 $\mathrm{mm}$ anterior to the occipital ridge (for access to the superior colliculus). ${ }^{35} \mathrm{~S}$-methionine $(0.12 \mathrm{mCi}), \mathrm{ly}$ ophilized and resuspended in sterile distilled water containing $0.1 \mathrm{~mm}$ dithiothreitol (DTT) (in a total volume of $15 \mu \mathrm{l}$ ), was injected directly into the superior colliculus, the lateral geniculate nucleus, or near the optic nerve and optic tract by means of a Hamilton No. 727 needle attached to a Hamilton syringe (Hamilton Co., Reno, NV). After $1 \mathrm{hr}$, the rabbit was killed by intravenous injection of a lethal dose of sodium pentobarbital, and the distal half of the left optic nerve, the left optic tract, the lateral geniculate nucleus, and the superior colliculus were removed and frozen on solid $\mathrm{CO}_{2}$.

Analytical methods. Visual system tissue samples were homogenized in a solution (H buffer; $4.4 \mathrm{ml}$ ) containing Tris (10 mM, $\mathrm{pH} 8.0$ ), EDTA $(5 \mathrm{~mm})$, DTT (2 mM), $O$-phenanthroline $(1 \mathrm{~mm})$, and phenylmethylsulfonyl fiuoride (PMSF; $1 \mathrm{~mm}$ ), using a motor-driven glass-on-glass homogenizer (Kontes, Vineland, NJ). Each homogenate was separated into a pellet and a soluble fraction by centrifugation at $100,000 \times g$ for $1 \mathrm{hr}$. The pellet (henceforth referred to as the particulate fraction) and an ether-washed TCA precipitate of the supernatant (the soluble fraction) were dissolved in a solution containing DTT $(2.5 \mathrm{~mm})$ and SDS $(0.5 \% \mathrm{wt} / \mathrm{vol})$ for nonequilibrium $\mathrm{pH}$ gradient electrophoresis (NEPHGE) gels, or DTT $(2.5 \mathrm{~mm})$ and SDS $(1.0 \% \mathrm{wt} / \mathrm{vol})$ for isoelectric focusing (IEF) gels, and heated to $60^{\circ} \mathrm{C}$ for $5 \mathrm{~min}$. After these samples had cooled to room temperature, an equal volume of a solution containing urea (4 M), DTT (2.5 mm), and Nonidet P-40 (10\% vol $/ \mathrm{vol})$ was added; urea was then added to produce a final concentration of $8 \mathrm{M}$. Prior to electrophoresis, each sample was centrifuged at $40,000 \times g_{a v}$ for 30 min at room temperature. This procedure solubilized $80-90 \%$ of the total radioactivity in each sample.

NEPHGE and IEF were performed as described by O'Farrell (1975) and by O'Farrell et al. (1977), except that the cylindrical gels used in the first-dimension were $11.5 \mathrm{~cm} \times 1.5 \mathrm{~mm}$ in diameter. NEPHGE gels contained $2 \%(\mathrm{vol} / \mathrm{vol})$ ampholytes (LKB; pH 3.5-10); IEF gels contained $1 \%(\mathrm{vol} / \mathrm{vol}), \mathrm{pH} 3.5-10$ and $1 \% \mathrm{pH}$ 5-7 ampholytes. NEPHGE gels were electrophoresed for $1600 \mathrm{~V}-\mathrm{hr}$. Second-dimension SDS-PAGE were run in the buffer system of Laemmli (1970); glycerol (15\% vol/ vol) was included in both the stacking and the running gels. The separating gel contained acrylamide $(10 \% \mathrm{wt} / \mathrm{vol})$, bisacrylamide $(0.3 \% \mathrm{wt} /$ $\mathrm{vol}$ ), and the stacking gel contained acrylamide ( $3 \% \mathrm{wt} / \mathrm{vol})$, and bisacrylamide $(0.09 \% \mathrm{wt} / \mathrm{vol})$. Fodrin polypeptides were separated on 2-dimensional gels that used SDS electrophoresis in the absence of urea in the first dimension, and SDS electrophoresis in the presence of $8 \mathrm{M}$ urea in the second dimension (Carmon et al., 1978). Gels were stained and destained as described by Fairbanks et al. (1971), processed for fluorography by the method of Bonner and Laskey (1974), dried under reduced pressure, and fluorographed on Kodak Royal X-Omat AR film that had been preflashed to an optical density of 0.15 (Laskey and Mills, 1975). The fluorographs were exposed for 3-106 d at $-70^{\circ} \mathrm{C}$.

The relative labeling of synapsin polypeptides that had been separated on 2-dimensional NEPHGE-SDS polyacrylamide gels or of fodrin polypeptides separated on 2-dimensional SDS-SDS/urea gels was determined by densitometry of the fluorographs. The spot corresponding to labeled synapsin Ia or to alpha or beta fodrin was scanned through its longest dimension using a scanning microdensitometer (Joyce-Loebl, Newcastle-on-Tyne, UK). The slit length was greater than the maximum width of the fluorographic image. To assure that the measured optical density was a linear function of the fluorographic exposure, different exposures of the same gel were scanned to verify that the optical density was proportional to the exposure time. The areas under the scanned peaks were determined by use of a Summagraphics BitPad interfaced with a PDP11-44 computer. The arcas under the scanned peaks were corrected for fluorographic background optical density, the amount of tissue loaded on the gel, differing fluorographic exposure times, the amount of isotope injected, and isotopic decay between the time of injection and the midpoint of the fluorographic exposure; these corrected areas provided a measure of the relative labeling of synapsin or fodrin in the different tissue samples. This measure was expressed as follows: 


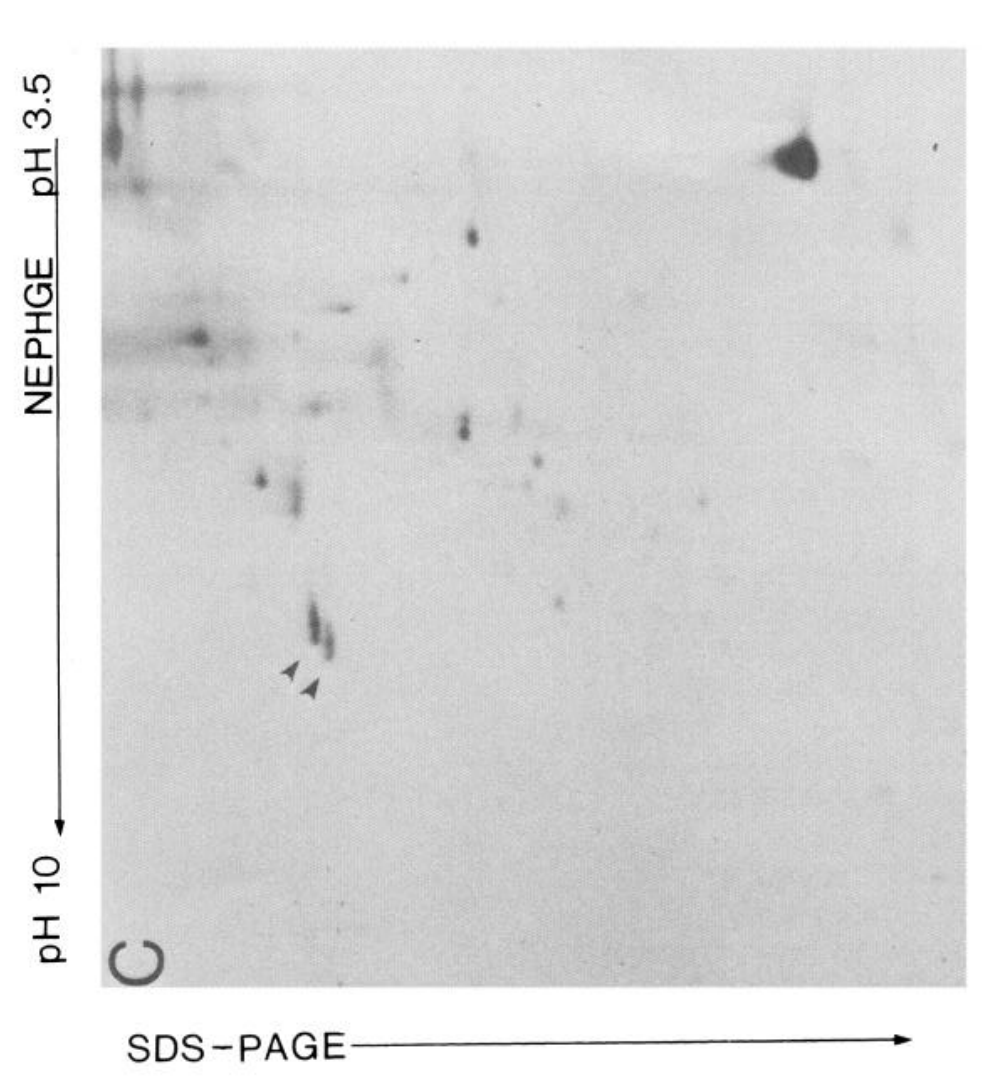

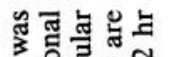

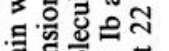

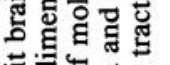

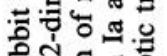

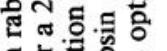

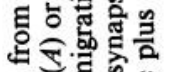

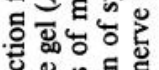

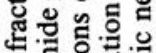

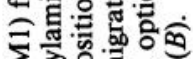
대요의

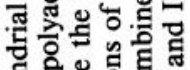

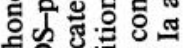

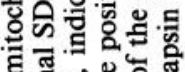
졍 สํํㅇํㅇำ 过记

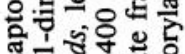

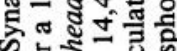

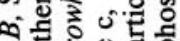
तै 西

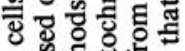

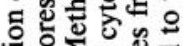
क力口े क

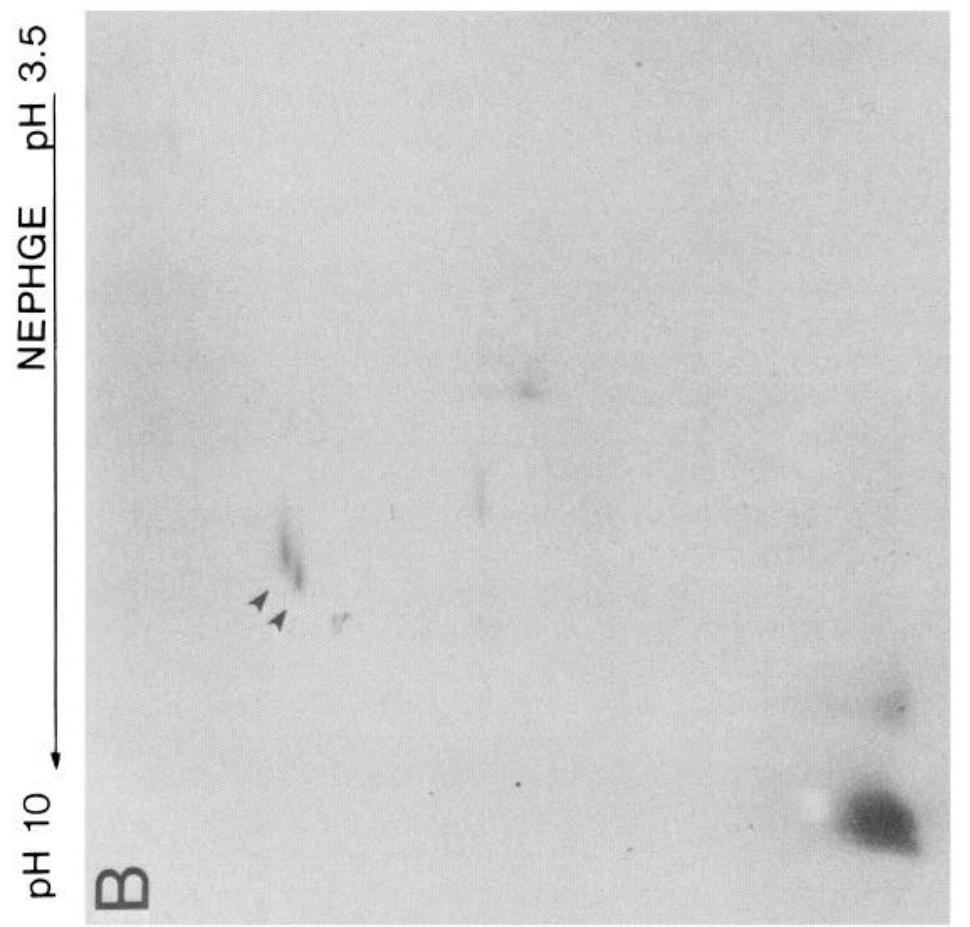

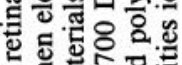

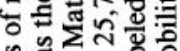
呵. 诺尊 을 ช0

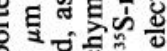
证 4 때을 중 융요의 릴 管 ङ

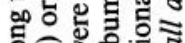

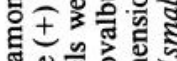
\& 80

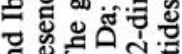
न ज为 댇워

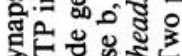
करषण 웜 둥혀 द्व

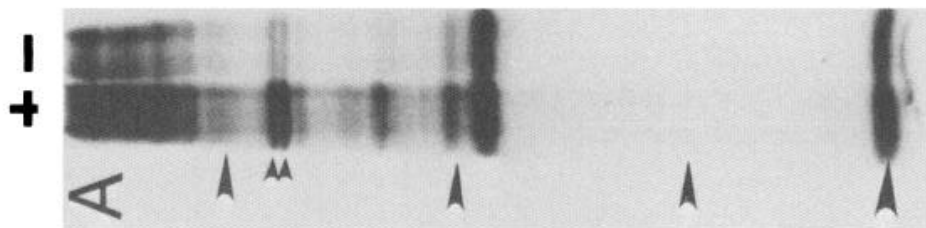

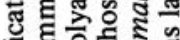

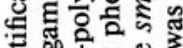

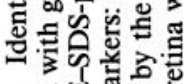

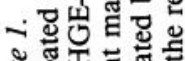

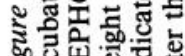

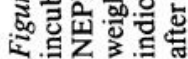


1 unit $=1 \mathrm{~mm}^{2}$ (area using the 1.6 wedge of the Joyce-Loebl densitometer) $/ 0.5 \mathrm{mCi}$ of ${ }^{35} \mathrm{~S}$-methionine injected into the eye per $10 \mathrm{~d}$ of fluorographic exposure for the entire tissue sample.

\section{Results}

Identification of synapsin I-like proteins among the axonally transported polypeptides of rabbit retinal ganglion cells

To determine the electrophoretic mobility of synapsin Ia and Ib on 2-dimensional gels, we prepared a synaptosomal-mitochondrial (M1) subcellular fraction from rabbit brain, as described in Materials and Methods, and incubated it with ${ }^{32} \mathrm{P}$ ATP in the presence or absence of $5 \mu \mathrm{M}$ CAMP, which characteristically stimulates the phosphorylation of synapsin I (Ueda et al., 1973; Ueda and Greengard, 1977). Figure 1 shows that the phosphorylation of 2 polypeptides with the same apparent molecular weights as synapsin Ia and $\mathrm{Ib}(86,000$ and 80,000 Da) was stimulated 3-5-fold by cAMP (Fig. $1 A$ ). When these polypeptides were electrophoresed on 2-dimensional gels employing NEPHGE, followed by SDS-PAGE (O'Farrell et al., 1977), they migrated to a position indicative of a high net positive charge (Fig. $1 B$ ), which is also a characteristic of synapsin I (Ueda and Greengard, 1977). These polypeptides were not effectively resolved when IEF was employed as the first dimension; typically, very basic proteins such as synapsin I are not well resolved by this system (O'Farrell, 1975). Because the cAMPstimulated phosphorylation and electrophoretic behavior of these phosphoproteins conforms to that expected for synapsin Ia and Ib (Ueda et al., 1973; Ueda and Greengard, 1977; Naito and Ueda, 1981; Sorensen and Babitch, 1984), we have used their electrophoretic mobility on NEPHGE 2-dimensional gels to identify synapsin I-like polypeptides among the axonally transported proteins.

We labeled the newly synthesized proteins of the retinal ganglion cells of rabbits by injecting ${ }^{3} \mathrm{~S}$-methionine into their eyes, and subsequently analyzed the radiolabeling of synapsin I-like polypeptides (by means of 2-dimensional gel electrophoresis, followed by fluorography) in the tissues that contain the axons and synaptic terminals of these neurons. The optic nerve tissue ipsilateral to the injected eye contains the portion of the axons situated between 3 and $15 \mathrm{~mm}$ from the eye, whereas the contralateral optic tract contains axon segments between approximately 15 and $25 \mathrm{~mm}$ from the injected eye. The contralateral lateral geniculate nucleus and superior colliculus contain synaptic endings situated approximately 25 and $35 \mathrm{~mm}$ from the injected eye, respectively, as well as preterminal axon segments. The tissue used to analyze the lateral geniculate nucleus also contains axons of passage of the optic tract (Giolli and Guthrie, 1969). Radiolabeled synapsin I-like polypeptides were not detected in any of these tissues $2.8 \mathrm{hr}$ after the eye was labeled. They were barely detected at $3.5 \mathrm{hr}$, and were easily detected by $22 \mathrm{hr}$ in the optic nerve and optic tract (Fig. 1C).

\section{Time course of labeling of synapsin I-like proteins}

Figure 2 summarizes the initial time course of labeling of synapsin I-like proteins in the retinal ganglion cell axons. At approximately $1 \mathrm{hr}$ intervals after the left eye was labeled, synapsin I-like proteins were analyzed in the right lateral geniculate nucleus and superior colliculus and in 5 pieces of the left optic nerve and right optic tract that contained segments of the axon progressively more distal from the injected eye. Labeled synapsin I-like protein was detected in the lateral geniculate nucleus by $4 \mathrm{hr}$ after the eye was labeled, indicating that it must have
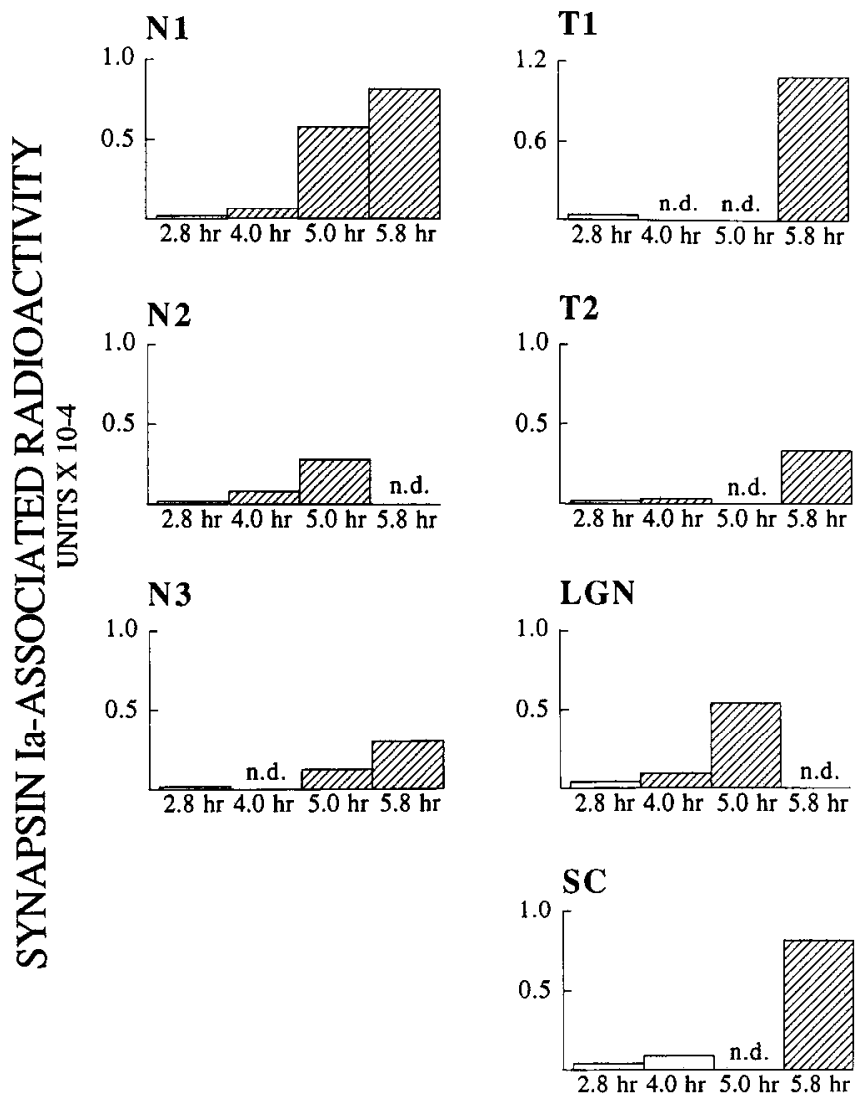

Figure 2. Distribution of labeled synapsin in segments of rabbit retinal ganglion cell axons at short intervals after the retina was labeled with ${ }^{35} \mathrm{~S}-$-methionine. The synapsin I-associated radioactivity was determined by densitometry of 2-dimensional fluorographs of proteins in particulate fractions obtained from three $4 \mathrm{~mm}$ segments of the optic nerve $(\mathrm{Nl}$, $N 2$, and $N 3$ ), two $6 \mathrm{~mm}$ segments of the optic tract $(T 1, T 2)$ progressively more distal to the eye, and from the lateral geniculate nucleus ( $L G N)$ and superior colliculus $(S C)$ at the indicated intervals after the retina was labeled. The data from each time point are from a single rabbit. The open bars at 2.8 and $4.0 \mathrm{hr}$ show the maximum amount of laheled synapsin I that could have escaped detection in these samples, where no synapsin I was detected. n.d., Synapsin I was not determined. Units are defined in Materials and Methods (Analytical Methods).

traveled $25 \mathrm{~mm}$ in no more than $4 \mathrm{hr}$; this corresponds to a minimum velocity of $150 \mathrm{~mm} / \mathrm{d}$. Considering that labeled synapsin I-like proteins were not detected anywhere in the system prior to $2.8 \mathrm{hr}$, this synapsin I-like protein most likely moved approximately $20 \mathrm{~mm}$ (the distance between the optic nerve and the lateral geniculate nucleus) in $1.2 \mathrm{hr}$, at a velocity of approximately $400 \mathrm{~mm} / \mathrm{d}$, similar to the velocities (greater than $240 \mathrm{~mm} / \mathrm{d}$ ) previously observed in this system for the most rapidly transported (group I) proteins (Willard et al., 1974).

Figures 3 and 4 show representative fluorographs illustrating the time courses of labeling of synapsin I-like proteins in the optic tract and superior colliculus at later times after the retina was labeled. The results of such experiments are summarized in Figure 5. Two aspects are striking. First, the amount of labeled synapsin I-like protein in each of the tissues was constant between $6 \mathrm{hr}$ and 1-2 d; however, it increased approximately 5 -fold in the superior colliculus and the lateral geniculate nucleus between 1 and $6 \mathrm{~d}$. Second, labeled synapsin declined rapidly in the optic nerve (between 4 and $6 \mathrm{~d}$ ) and in the optic tract and lateral geniculate nucleus (between 6 and $8 \mathrm{~d}$ ), but remained 

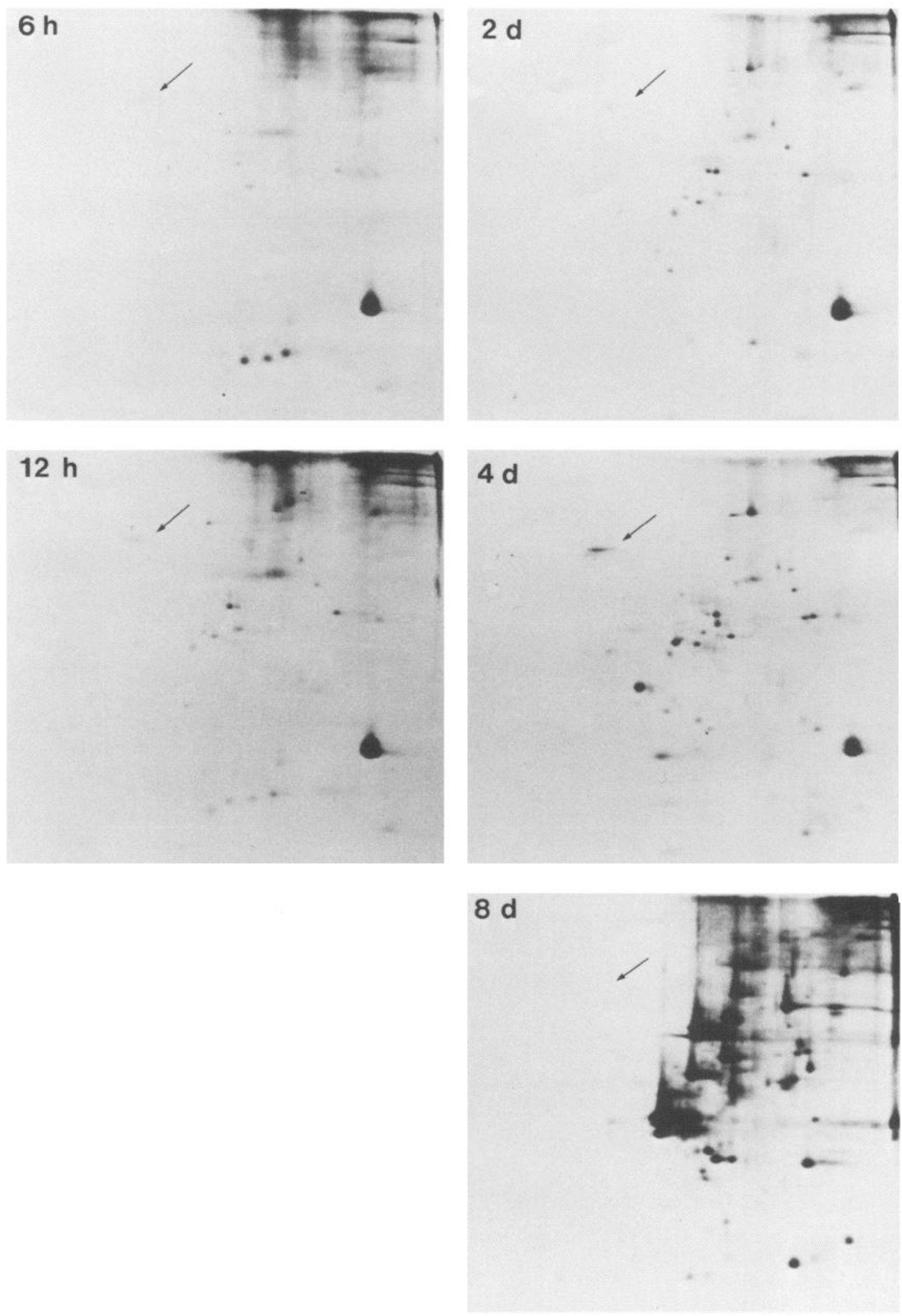

Figure 3. Time course of appearance of ${ }^{35} \mathrm{~S}$-methionine-labeled synapsin I in particulate fractions of the rabbit optic tract. At the indicated times after the retina was labeled with ${ }^{35}$ S-methionine, the labeled polypeptides in a particulate fraction of each animal's optic tract were analyzed by electrophoresis on NEPHGE-SDS-polyacrylamide gels followed by fluorography. The arrows show the position of synapsin I-like proteins. The following portions of the particulate fraction of the optic tracts were electrophoresed: 6 and $12 \mathrm{hr}, 5 \% ; 2,4$, and $8 \mathrm{~d}, 9 \%$. The fluorographic exposure times were $6 \mathrm{hr}$ time point, $65 \mathrm{~d}$ exposure; $12 \mathrm{hr}$ time point, $34 \mathrm{~d}$ exposure; $2 \mathrm{~d}$ time point, $29 \mathrm{~d}$ exposure; $4 \mathrm{~d}$ time point, $17.5 \mathrm{~d}$ exposure; $8 \mathrm{~d}$ time point, $45 \mathrm{~d}$ exposure. 

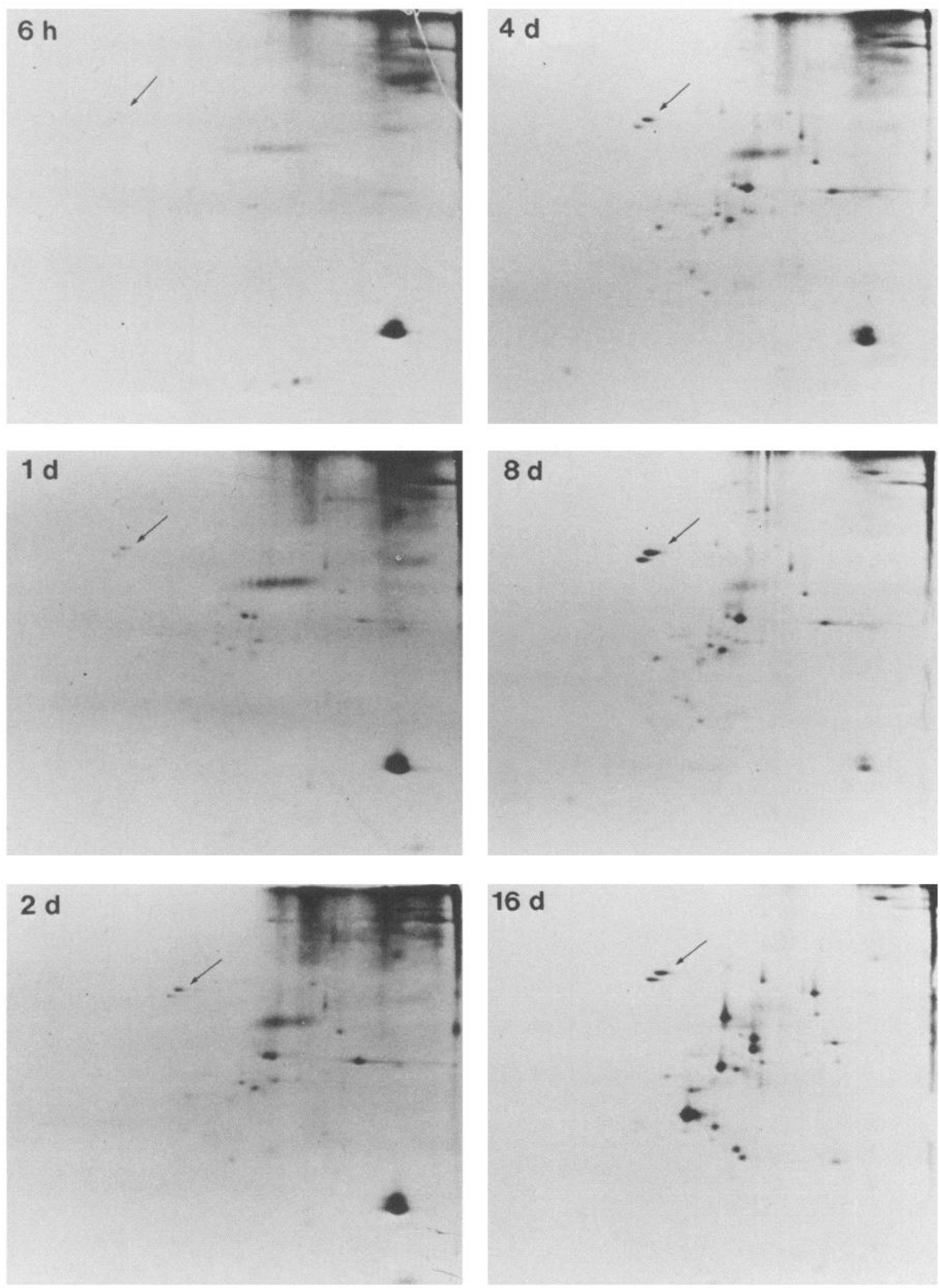

Figure 4. Time course of appearance of ${ }^{35} \mathrm{~S}$-methionine-labeled synapsin I in particulate fractions of the rabbit superior colliculus. Fluorographs of 2-dimensional gels of the particulate fractions of the superior colliculi from the same rabbits as in Figure 3 . The $6 \mathrm{hr}$ and $1 \mathrm{~d}$ samples were electrophoresed in the NEPHGE dimension for $2000 \mathrm{~V}-\mathrm{hr}$, whereas the remaining samples were electrophoresed for $1600 \mathrm{~V}$-hr. The position of migration of synapsin $\mathrm{I}$ is indicated by arrows. The same portion $(2 \%)$ of the particulate fraction of each superior colliculus was electrophoresed on each gel. Fluorographs were exposed for the following time periods: $6 \mathrm{hr}$ time point, $48 \mathrm{~d}$ exposure; $1 \mathrm{~d}$ time point, $34 \mathrm{~d}$ exposure; $2 \mathrm{~d}$ time point, $34 \mathrm{~d}$ exposure; 4 and $8 \mathrm{~d}$ time points, $26 \mathrm{~d}$ exposure; $16 \mathrm{~d}$ time point, $24 \mathrm{~d}$ exposure. 

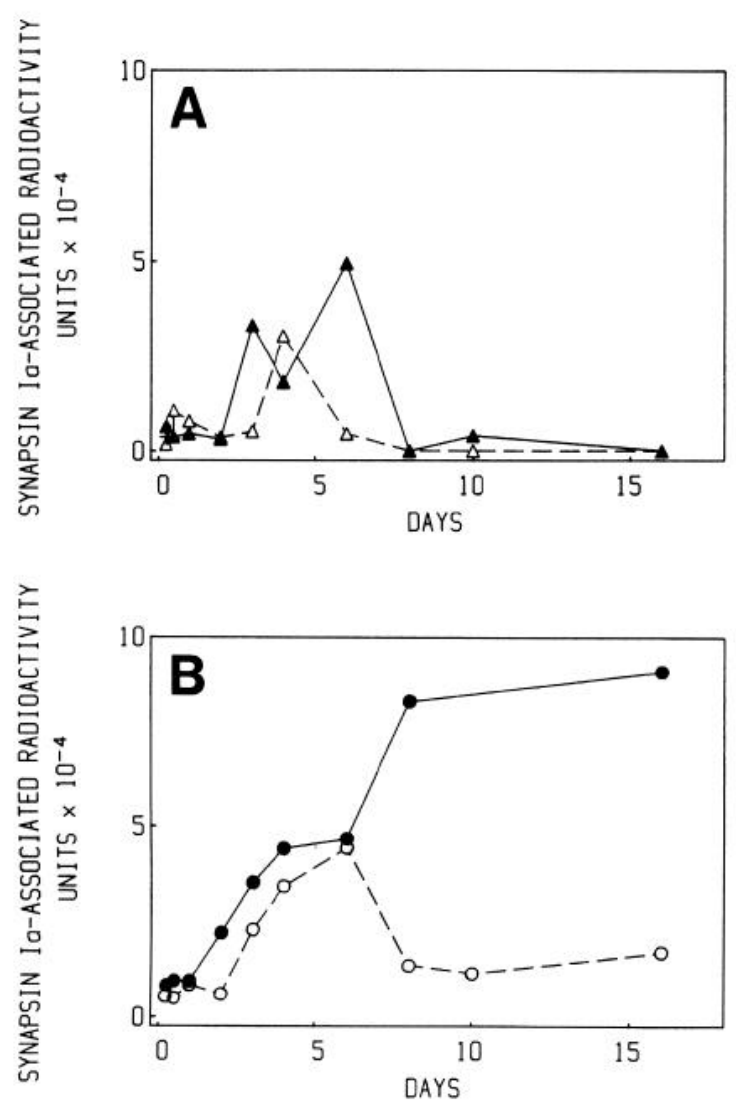

Figure 5. Relative amount of radioactivity associated with synapsin $I$ in rabbit visual system tissues as a function of time after intravitreal injection of ${ }^{35} \mathrm{~S}$-methionine. The relative labeling of synapsin $\mathrm{I}$ in the optic nerve ( $A$, open triangles), optic tract $(A$, closed triangles), lateral geniculate nucleus $(B$, open circles), and superior colliculus $(B$, closed circles), as determined by densitometry of fluorographs of 2-dimensional gels. The points represent either the value from one animal or the average of the values obtained from 2 or 3 animals. In the cases where more than one animal was used, the difference between the extreme values as a percentage of the highest value was as follows: superior colliculus, $29 \%$ (4 d), $5.7 \%$ (8 d); lateral geniculate nucleus, $69 \%$ (1 d); optic tract, $41 \%(6 \mathrm{hr}),<10 \%$ ( 8 and $16 \mathrm{~d}$ ), $31 \%(4 \mathrm{~d})$; optic nerve, $84 \%$ $(12 \mathrm{hr})$ and $63 \%(1 \mathrm{~d})$. Units are defined in Materials and Methods (Analytical methods).

at elevated levels in the superior colliculus and at detectable levels in the lateral geniculate nucleus for as long as $16 \mathrm{~d}$. These results indicate that a large fraction of the newly synthesized synapsin I-like protein does not enter these axon segments until more than $1 \mathrm{~d}$ after its synthesis. This slowly labeled synapsin I-like protein disappears more rapidly from the tissues that contain only axons than from those that also contain synaptic terminals.

\section{Time- and tissue-dependent differences in the electrophoretic mobility of recently synthesized synapsin I-like proteins}

We observed subtle but reproducible differences in the appearance of the fluorographic spots generated by radiolabeled synapsin 1 that had been electrophoresed on 2-dimensional gels; these differences depended on the postsynthetic time interval and the location in retinal ganglion cell axons (Fig. 6). At short intervals ( $6 \mathrm{hr}$ to $1 \mathrm{~d}$ ) after its synthesis, labeled synapsin I-like protein in the axons of the optic nerve and tract invariably appeared as a row of 4-7 distinct spots (Fig. $6 a$ ); at later times (2-6 d), the labeled synapsin I-like protein in the nerve and tract appeared as a streak in which individual spots were indiscernible (Fig. $6 b$ ). In the superior colliculus, the morphology of the fluorographic spots was different than either of these axonal forms; the spots were more discrete and circular, and less elongated in the direction of the NEPHGE separation (Fig. 6c). In the lateral geniculate nucleus, the appearance of the spot produced by labeled synapsin I-like protein was most similar in form to that in the superior colliculus, but was less completely differentiated from the form in the optic tract. These differences in the electrophoretic resolution of synapsin I-like protein suggest that at least 2 distinct populations of synapsin I-like proteins occupy the axons at different times after their synthesis, and that an additional population occupies the terminal-containing structures. These different populations could represent the products of different genes, or (as is most likely in the case of the terminal form), different degrees of posttranslational modification of the same gene product.

\section{Comparison of the transport of synapsin I-like protein and fodrin}

Synapsin I has been reported to bind to erythrocyte spectrin and its nonerythrocyte analog, fodrin (Baines and Bennett, 1985; Goodman, 1986). In view of this potential for interaction, we compared the time course of labeling of fodrin and of synapsin I-like proteins in retinal ganglion cell axons of the same rabbits (Fig. 7). Labeled synapsin I-like protein was detected before labeled fodrin in the optic tract and superior colliculus, indicating that a population of synapsin I-like protein is transported more rapidly than the most rapidly transported population of fodrin. This delayed appearance of labeled fodrin relative to
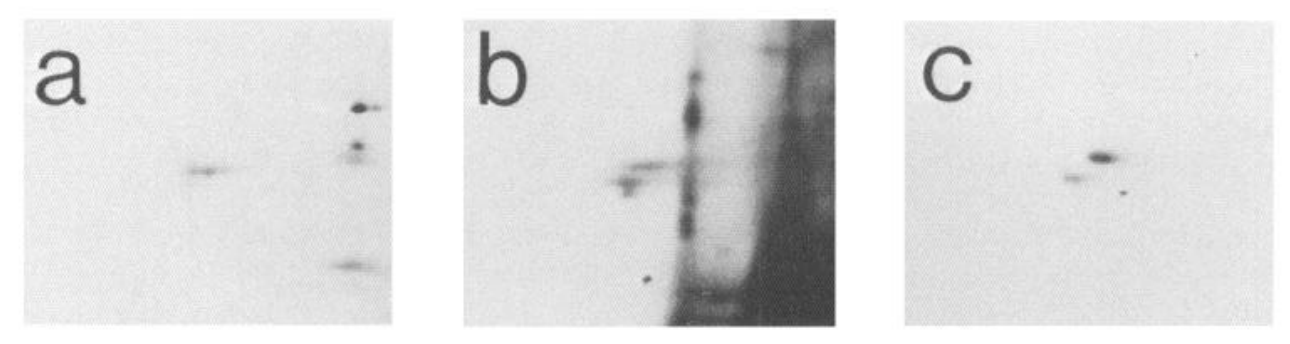

Figure 6. Time and tissue-dependent changes in the electrophoretic resolution of newly synthesized, axonally transported synapsin I. Particulate fractions from visual system tissues of rabbits that had received intravitreal injections of ${ }^{35} \mathrm{~S}$-methionine at the indicated intervals prior to being killed were prepared for 2-dimensional NEPHGE/SDS-PAGE and were electrophoresed under identical conditions. Each part shows only the portion of the fluorographic image that contains labeled synapsin Ia and Ib. $a$, Optic nerve, $12 \mathrm{hr}$ survival. $b$, Optic nerve, $4 \mathrm{~d}$ survival. $c$, Superior colliculus, $4 \mathrm{~d}$ survival. 
labeled synapsin I-like protein cannot be readily attributed to a difference in the sensitivity of detection of the 2 proteins because, at the time of maximum labeling, approximately 10 fold more radioactivity was associated with fodrin than with synapsin I-like protein. A second difference was that the labeled fodrin persisted in the optic nerve and optic tract for a much longer period than did labeled synapsin I-like protein. These differences are consistent with previous observations that different populations of fodrin are transported at the velocities of group II (40-80 mm/d), groups III and IV $(2-8 \mathrm{~mm} / \mathrm{d})$, and group V (approximately $1 \mathrm{~mm} / \mathrm{d}$ ) (Willard et al., 1974; Lorenz and Willard, 1978; Cheney et al., 1983). Hence, the most rapidly transported (group I) synapsin I-like protein moved more rapidly than the most rapidly transported (group II) population of fodrin, whereas the group $\mathrm{V}$ population of fodrin moved more slowly than the most slowly moving synapsin I-like protein. The rate of accumulation of label associated with fodrin and synapsin 1-like protein in the optic tract was similar between 1 and $6 \mathrm{~d}$, an interval that would include the appearance of the proteins of groups II and IV.

\section{Controls}

We considered the possibility that the labeled synapsin I-like protein observed in the foregoing experiments might have arisen by means of the local incorporation of systemically supplied label into the tissues of the visual system, rather than by transport from the retina. To evaluate this possibility, we electrophoresed tissue samples containing the axons projecting from the unlabeled eye (which should also have been exposed to systemic label, but should not contain axonally transported proteins) on NEPGHE 2-dimensional gels; when these gels were fluorographed, no labeled polypeptides were detected after exposures of twice the durations that were used for the experimental samples. We also considered the possibility that synapsin might be synthesized locally in the visual system tissues from labeled precursors specifically supplied by axonal transport. To address this possibility, we directly labeled locally synthesized polypeptides by injection of ${ }^{35} \mathrm{~S}$-methionine into each tissue in vivo, and compared these locally synthesized polypeptides with those that were labeled in the same tissues after intravitreal injection of ${ }^{35}$ S-methionine (Fig. 8). Synapsin I-like polypeptides were not detected among the polypeptides synthesized locally by the optic nerve and tract (Fig. 8, $A, B$ ), indicating that the cells of these tissues do not synthesize appreciable amounts of this protein. The labeled synapsin I-like proteins in the optic nerve and optic tract, following labeling of the retina, must therefore be supplied by axonal transport. When ${ }^{35} \mathrm{~S}$-methionine was directly injected into the superior colliculus or lateral geniculate nucleus, synapsin I-like protein was detected among the locally synthesized proteins; it composed a minor fraction of the total (Fig. 8, C, $D$ ). If the capacity of the superior colliculus and lateral geniculate nucleus cells to synthesize synapsin I-like protein had contributed significantly to the labeled synapsin I-like protein that we observed in these tissues after the retina was labeled, it would be expected that the proteins that were most highly labeled by local synthesis should also be present. A comparison of Figure 8 with Figures $1 C, 3$, and 4 shows that the major locally labeled polypeptides (Fig. 8, arrowheads) did not become labeled appreciably after the eye was labeled. Therefore, in each of the tissues examined, it is reasonable to attribute the labeling of synapsin I-like protein after the eye was labeled to axonal transport in the retinal ganglion cells.
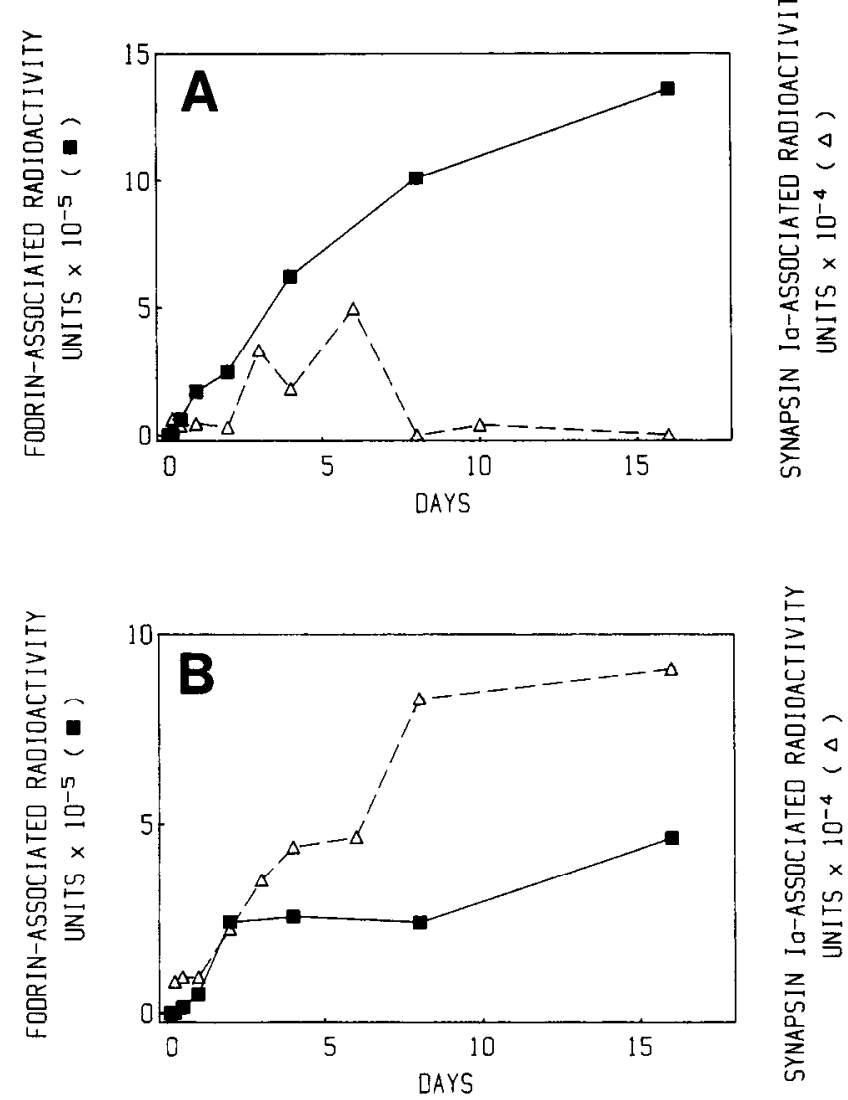

Figure 7. Comparison of the time courses of labeling of synapsin I and of fodrin in the optic tract $(A)$ and the superior colliculus $(B)$ after the retina was labeled with ${ }^{35} \mathrm{~S}$-methionine. Synapsin I- (triangles) and fodrin-associated (squares) radioactivity was determined by densitometric analysis of 2-dimensional fluorograms as described in Materials and Methods. Units are defined in Materials and Methods (Analytical methods).

We have reported here the labeling of synapsin I-like protein obtained from a particulate fraction of the visual system tissues. The soluble fraction (the supernatant of a $100,000 \times g$ centrifugation) did not contain sufficient labeled synapsin I to be detected by a $100 \mathrm{~d}$ fluorographic exposure at any of the survival times that were studied.

\section{Discussion}

The preceding experiments show that a population of synapsin I-like protein is transported rapidly down the axons of retinal ganglion cell neurons. The transported synapsin I-like protein was identified among the axonally transported proteins by the similarity of its electrophoretic mobility on 2-dimensional NEPHGE-SDS-polyacrylamide gels to rabbit brain synapsin I, which was, in turn, identified by the molecular weights and high positive charge of its 2 subunits, and by their cAMP-stimulated phosphorylation (Ueda and Greengard, 1977). Radioactive synapsin I-like protein was first detected in all of the tissues containing the axons and synaptic terminals of retinal ganglion cells between 2.8 and $6 \mathrm{hr}$ after the cell bodies were labeled with ${ }^{35} \mathrm{~S}$ methionine. Hence, after a delay of approximately $3 \mathrm{hr}$, newly synthcsized synapsin I-likc protcin is axonally transported in retinal ganglion cells at velocities of approximately $400 \mathrm{~mm} / \mathrm{d}$, 

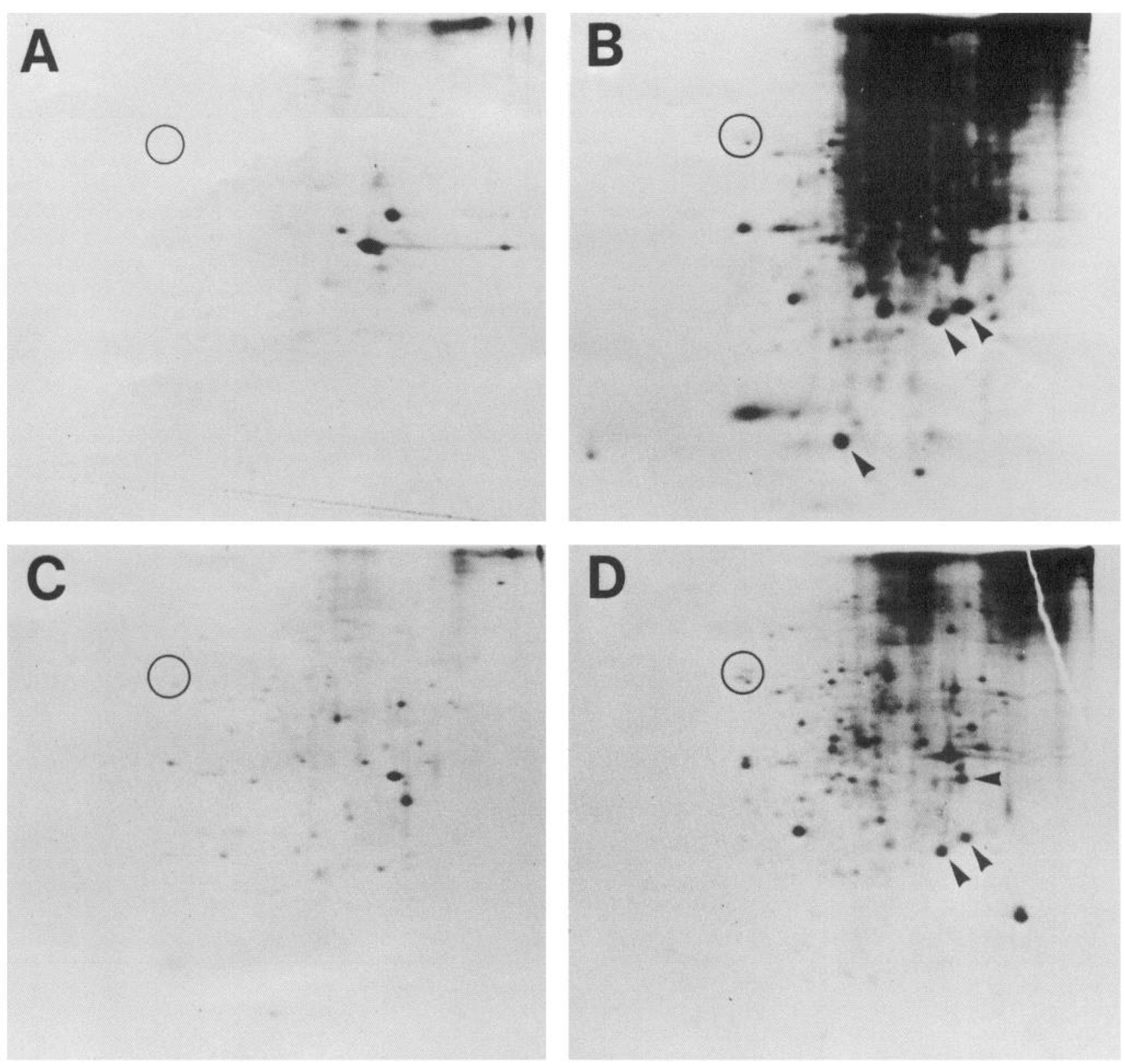

Figure 8. Two-dimensional electrophoretic analysis of locally synthesized polypeptides of rabbit visual system tissues. The figure shows 2-dimensional fluorograms of particulate fractions of optic nerve $(A)$, optic tract $(B)$, lateral geniculate nucleus $(C)$, and superior colliculus $(D)$ obtained from a rabbit $50 \mathrm{~min}$ after ${ }^{35} \mathrm{~S}$-methionine was injected directly into these tissues. The expected position of synapsin I is circled. Prominent locally labeled polypeptides are indicated by arrowheads.

similar to previously characterized group I proteins, the most rapidly transported proteins in this system.

The identification of synapsin I-like proteins as components of group I serves to define further the molecular composition of this group of rapidly transported proteins. The solubility properties of group 1 proteins, and their sedimention on equilibrium density gradients indicate that most are associated with membranous organelles (e.g., Lorenz and Willard, 1978). For example, the Na,K-ATPase, an integral protein of the plasma membrane, is a component of group I (Baitinger and Willard, 1981; Baitinger, 1984; Specht and Sweadner, 1984). In other neuronal systems, markers for synaptic vesicles (e.g., dopamine$\beta$-hydroxylase and norepinephrine) have been reported to move with velocities similar to those of the most rapidly transported proteins (Brimijoin and Wiermaa, 1977; Goldberg et al., 1978), suggesting that materials destined to function in specialized neurotransmitter secretory vesicles, as well as proteins destined for the plasma membrane, are components of group I. It is likely that these group I proteins are components of membranous vesicles that are translocated to their destination along microtubule tracks (Vale et al., 1985). One explanation for the observation that synapsin I moves at velocities similar to those expected for synaptic vesicle components would be that a population of synapsin I molecules becomes associated with synaptic vesicles or their precursors shortly after it is synthesized, and is transported down the axon in association with these vesicular elements. These results are consistent with those of Booj et al. (1986) that synapsin I antigens accumulate at a nerve 
crush with kinetics that indicate a rapid rate of transport, and that the time course of accumulation of this material is similar (although not identical) to that of another synaptic vesicle-associated antigen.

Only a small fraction of the label associated with synapsin I-like proteins that eventually accumulated in the axons and synaptic terminals of the retinal ganglion cells arrived with a time course that unequivocally indicated a velocity as high as that of group I. For example, the amount of synapsin I-associated label in the superior colliculus $8 \mathrm{~d}$ after the retina was labeled was 10 times more than at any time prior to $3 \mathrm{~d}$. It is unlikely that this delayed and prolonged accumulation represented a prolonged synthesis of synapsin I-like protein, because previous experiments indicate that most of the ${ }^{35} \mathrm{~S}$-methionine injected into the rabbit vitreous remains available for incorporation into protein in retinal ganglion cell bodies for less than $3 \mathrm{hr}$ (Willard, 1984). Thus, most of the newly synthesized synapsin I-like protein must remain in the cell bodies (or in the portion of the axon closest to the cell body) for several days after it is synthesized. Because of the uncertainty of interpreting changes in the labeling of synapsin I in different rabbits (see legend to Fig. 5), we cannot entirely rule out the possibility that both this delayed-release and early-release synapsin I-like protein are the same population originating from a single slowly turning-over pool. However, several aspects of the data suggest that different populations of synapsin I-like proteins are transported from 3 different pools: a delayed-release slow-transport pool (delayed-slow), a delayed-release fast-transport pool (delayed-fast), in addition to the early-release fast-transport (earlyfast) pool described above.

The most suggestive indication of a slowly moving population of synapsin I-like protein is provided by the delayed increases in labeled synapsin I-like protein that occurred sequentially in tissues progressively more distal from the eye: in the optic nerve at $4 \mathrm{~d}$, the optic tract at $6 \mathrm{~d}$, and the superior colliculus at $8 \mathrm{~d}$ after the retina was labeled. These increases were followed by sequential decreases of labeled synapsin I-like protein from the optic nerve between 4 and $6 \mathrm{~d}$, and from the optic tract and lateral geniculate nucleus approximately $2 \mathrm{~d}$ later. This sequence could be generated by a population of synapsin I-like proteins that required $2 \mathrm{~d}$ for maturation in the cell body, and subsequently moved down the axons at a velocity of approximately $6 \mathrm{~mm} / \mathrm{d}$ (the velocity of groups III and IV). The amount of this labeled, slowly transported synapsin I-like protein in the superior colliculus did not appear to decline appreciably between 8 and $16 \mathrm{~d}$, suggesting that it resides for a longer period of time in the terminals than in the axon. On the other hand, most of the labeled synapsin I-like protein disappeared from the lateral geniculate nucleus, which also contains axon terminals within $2 \mathrm{~d}$ after it arrived. An explanation for this difference is that, because the tissue used to analyze the lateral geniculate nucleus also included axons en route to the superior colliculus (Giolli and Guthrie, 1969), the rapid decline of labeled slowly transported synapsin I-like protein from this tissue could represent the exit of protein contained in these axons. This explanation is reasonable if the superior colliculus contains approximately 6 times as many synaptic endings of synapsin I-transporting retinal ganglion cells as does the lateral geniculate nucleus, because we observed approximately 6-fold more labeled synapsin I-like protein in the superior colliculus at survival times of greater than $8 \mathrm{~d}$.

The possibility that synapsin I-like proteins are, in addition, released from a third, delayed-release fast-transported pool is raised by the acceleration of accumulation of labeled synapsin I-like protein that occurred at approximately $2 \mathrm{~d}$ in the optic tract, lateral geniculate nucleus, and superior colliculus. This apparent discontinuity could be generated by an additional population of synapsin I-like protein that is released from the cell body approximately $1 \mathrm{~d}$ after its synthesis, and moves down the axon with a velocity that is greater than $30 \mathrm{~mm} / \mathrm{d}$-a range that includes the velocities of group I and II proteins. Although the significance of this apparent acceleration of labeling is uncertain, it is noteworthy that between the time of first appearance of labeled synapsin I-like protein in the optic nerve and tract and the time (2-3 d) when the rate of accumulation of synapsin I-like protein began to increase, the morphology of the labeled synapsin spots on the fluorographs changed subtly. On the one hand, this morphological transition could reflect a time-dependent modification of synapsin I-like molecules that had been delivered to the axon shortly after their synthesis, i.e., from the early-rapid pool. More likely, it may represent the initial appearance in the axon of a new population of synapsin l-like molecules from this hypothetical delayed-rapid pool. Other labeled rapidly transported proteins appear in the axon with time courses suggesting that they are released from multiple pools in the cell body (Berry, 1980; Baitinger, 1984), indicating that such multiple pools may be a general characteristic of rapidly transported proteins.

One possible relationship between the early and delayed rapidly transported synapsin I-like proteins is suggested by the observation that in certain secretory cells a population of newly synthesized secretory peptides is transiently and constitutively released from the cell, whereas a second population is packaged in secretory vesicles and undergoes additional posttranslational modification: only then can it be released in response to secretagogues (Tartakoff and Vassalli, 1978; Gumbiner and Kelly, 1982). Perhaps synapsin I-like proteins (and certain other group I proteins) are released into the axon from 2 analogous pools, and the alteration in the appearance of the fluorographic spots reflects posttranslational modifications that occurred during the prolonged maturation of this delayed-released pool of synapsin I-like proteins.

Many proteins (e.g., neurofilament proteins, spectrin, tubulin), are produced in a variety of forms that differ from one another either in their primary amino acid sequence or in their posttranslational modifications (e.g., Cleveland et al., 1980; Goldstein et al., 1983; Lazarides and Nelson, 1983; Sternberger and Sternberger, 1983; Goodman, 1986); the different forms of such proteins are often spatially segregated, and presumably are tailored to perform most efficiently the function of that protein in a particular cell, or in a particular compartment of a cell. The suggestive evidence that different populations of synapsin I-like proteins may arise from different pools raises the question of whether such populations could be functionally different. Although this question cannot be answered definitively from the results of the experiments reported here, the following considerations are relevant. Both the early- and delayed-fast populations of synapsin I-like proteins would move at velocities expected for components of a synaptic vesicle, and both are therefore good candidates to account for synaptic vesicle-associated synapsin I. Furthermore, these fast populations may undergo modifications in the axon terminal (reflected in their altered appearance on electrophoretograms of the supcrior colliculus), and the delayed-fast population appears to accumulate 
in terminal-containing structures; these properties could contribute to the terminal-specific location of synapsin I observed in most immunohistochemical experiments (De Camilli et al., $1983 \mathrm{a}, \mathrm{b})$. On the other hand, certain immunocytochemical evidence has suggested that additional antigenically related proteins may occupy axons, cell bodies, and dendrites, and may be associated with the cytoskeleton (Goldenring et al., 1986; Goodman, 1986). The delayed-slow synapsin I-like protein would be a candidate for such an axonal, cytoskeleton-associated form because it would be transported as a component of groups III and IV, which serve to convey such cytoskeletal proteins as actin, myosin, and a population of the spectrin-like protein fodrin, with which synapsin I can interact in vitro. Fodrin is most concentrated in the region beneath the plasma membrane, and it has been speculated that the movement of group IV may represent in part the movement of this membrane cytoskeleton (Levine et al., 1982; Levine and Willard, 1983), as well as elements of the internal cytoskeletal matrix (Willard et al., 1979; Black and Lasek, 1980). The ability of synapsin I to enhance the binding of actin to the multifunctional cross-linking protein fodrin (Hirokawa et al., 1983) in a manner that depends on the phosphorylation state of synapsin I (Krebs et al., 1986b) suggests that a synapsin I-like protein could serve to regulate interactions between elements of the cytoskeleton. [Functionally, synapsin I appears to be related to the erythrocyte protein designated band 4.1 ; both bind to a similar site on spectrin-like proteins, and thereby enhance the binding of spectrin-like proteins to actin (Ungewickell et al., 1979; Fowler and Taylor, 1980; Baines and Bennett, 1985; Bennett, 1985; Goodman, 1986; Krebs et al., 1986a, b). However, the structural homology between synapsin I and band 4.1 appcars limitcd (Conboy ct al., 1986; Krebs et al., 1986a; McCaffery and DeGennaro, 1986), and another neuronal protein, designated amelin, which should not have been detected in our experiments, appears to have a greater structural homology to band 4.1 (Krebs et al., 1986c).] The prolonged residence of the delayed-slow synapsin I-like protein in the terminal-containing superior colliculus suggests that it performs a function in the terminals (e.g., participation in synaptic transmission), as well as in the axon (e.g., regulation of interactions between elements of the axonal cytoskeleton). For example, it has been suggested that the calcium-dependent phosphorylation of synapsin I in the synaptic terminals may serve to disassociate the actin-fodrin network underlying the synaptic terminal, allowing synaptic vesicles to fuse with the synaptic membrane (Krebs et al., 1986b). Finally, it may be significant that the transport velocity of the presumptive delayed-fast synapsin I-like protein may be similar to that of another population of fodrin, a component of group II. Perhaps this fodrin and synapsin I-like protein are associated with moving organelles such as mitochondria and vesicles, which are constituents of group II; fodrin has been detected in association with such organelles (Zagon et al., 1984; Koenig et al., 1985), as well as with the membrane cytoskeleton (Levine and Willard, 1981).

In summary, these observations show that synapsin I-like proteins are axonally transported rapidly, at the velocity expected for certain other constituents of synaptic vesicles. In addition, they raise the possibility that a second (delayed-rapid) population of synapsin I-like proteins undergoes delayed transport at group I or II velocities (possibly in association with intraaxonal fodrin-associated organelles) and that a third population (delayed-slow) is transported slowly (possibly in association with the fodrin of the submembrane cytoskeleton). Synapsin I is not a component of the most slowly moving transported proteins, group V, which serves to convey the neurofilament proteins. It is probable that synapsin I-like proteins become modified when they reach the synaptic terminals, possibly a reflection of their conversion to a form involved in vesicle release.

\section{References}

Baines, A. J., and V. Bennett (1985) Synapsin I is a spectrin-binding protein immunologically related to erythrocyte protein 4.1 . Nature 315: 410-413.

Baitinger, C. R. (1984) Membrane protein axonal transport. Ph.D. thesis, Washington University School of Medicine, St. Louis, MO.

Baitinger, C. R., and M. Willard (1981) Axonal transport of $\mathrm{Na}^{+}-\mathrm{K}^{+}$ ATPase and protein I in retinal ganglion cells. Soc. Neurosci. Abstr. 7: 742 .

Bennett, V. (1985) The membrane skeleton of human erythrocytes and its implications for more complex cells. Annu. Rev. Biochem. 54: $273-304$

Bennett, V., J. Davis, and W. E. Fowler (1982) Brain spectrin, a membrane-associated protein related in structure and function to erythrocyte spectrin. Nature 299: 126-131.

Berry, R. W. (1980) Evidence for multiple somatic pools of individual axonally transported proteins. J. Cell Biol. 87: 379-385.

Black, M. M., and R. J. Lasek (1979) Axonal transport of actin: Slow component $\mathbf{b}$ is the principal source of actin for the axon. Brain Res. 171: 401-413.

Black, M. M., and R. J. Lasek (1980) Slow components of axonal transport: Two cytoskeletal networks. J. Cell Biol. 86: 616-623.

Bonner, W. M., and R. J. Laskey (1974) A film detection method for tritium-labeled proteins and nucleic acids in polyacrylamide gels. Eur. J. Biochem. 46: 83-88.

Booj, S., P. A. Larsson, A. G. Dahllof, and A. Dahlstrom (1986) Axonal-transport of synapsin-like and cholinergic synaptic vesicle-like material: Further immunohistochemical evidence for transport of axonal cholinergic transmitter vesicles in motor neurons. Acta Physiol. Scand. 128: 155-165.

Brady, S. T., and R. J. Lasek (1981) Nerve-specific enolase and creatine phosphokinase in axonal transport: Soluble proteins and the axoplasmic matrix. Cell 23: 515-523.

Brady, S. T., M. Tyell, K. Herict, and R. J. Lasek (1981) Axonal transport of calmodulin: A physiological approach to identification of long-term associations between proteins. J. Cell Biol. 89: 607-614.

Brimijoin, S., and M. J. Wiermaa (1977) Direct comparison of the rapid axonal transport of norepinephrine and dopamine- $\beta$-hydroxylase activity. J. Neurobiol. 8: 239-250.

Burridge, K., T. Kelly, and R. Mangeat (1982) Nonerythrocyte spectrins: Actin-membrane attachment proteins occurring in many cell types. J. Cell Biol. 95: 478-486.

Carmon, Y., S. Neuman, and D. Yaffe (1978) Synthesis of tropomyosin in myogenic cultures and in RNA-directed cell free systems: Qualitative changes in the polypeptides. Cell 14: 393-401.

Cheney, R., N. Hirokawa, J. Levine, and M. Willard (1983) Intracellular movement of fodrin. Cell Motil. 3: 649-655.

Cleveland, D. W., M. A. Lopata, R. J. MacDonald, N. J. Cowan, W. J. Rutter, and M. W. Kirschner (1980) Number and evolutionary conservation of $\mathrm{a}$ - and $\mathrm{b}$-tubulin and cytoplasmic $\mathrm{b}$ - and g-actin genes using specific cloned cDNA probes. Cell 20: 95-105.

Conboy, J., Y. W. Kan, S. B. Shohet, and N. Mohandas (1986) Molecular cloning of protein 4.1, a major structural element of the human erythrocyte membrane skeleton. Proc. Natl. Acad. Sci. USA 83:95129516.

De Camilli, P., R. Cameron, and P. Greengard (1983a) Synapsin I (protein I), a nerve terminal-specific phosphoprotein. I. Its general distribution in synapses of the central and peripheral nervous system demonstrated by immunofluorescence in frozen and plastic sections. J. Cell Biol. 96: 1337-1354.

De Camilli, P., S. M. Harris, Jr., W. B. Huttner, and P. Greengard (1983b) Synapsin I (protein I), a nerve terminal-specific phosphoprotein. II. Its specific association with synaptic vesicles demonstrated by immunocytochemistry in agarose-embedded synaptosomes. J. Cell Biol. 96: 1355-1373

de Robertis, E., G. R. De Lores Arnaiz, M. Alberici, R. W. Butcher, and E. W. Sutherland (1967) Subcellular distribution of adenyl cy- 
clase and cyclic phosphodiesterase in rat brain cortex. J. Biol. Chem. 242: 3487-3493.

Dolphin, A. C., and P. Greengard (1981) Serotonin stimulates phosphorylation of protein I in the facial motor nucleus of rat brain. Nature 289: 76-79.

Erickson, P. F., K. B. Seamon, B. W. Moore, R. S. Lasher, and L. N. Minier (1980) Axonal transport of the $\mathrm{Ca}^{2+}$-dependent protein modulator of $3^{\prime}: 5^{\prime}$-cyclic-AMP phosphodiesterase in the rabbit visual system. J. Neurochem. 35: 242-248.

Fairbanks, G., T. L. Steck, and D. F. H. Wallach (1971) Electrophoretic analysis of the major polypeptides of the human erythrocyte membrane. Biochemistry 10:2606-2617.

Forn, J., and P. Greengard (1978) Depolarizing agents and cyclic nucleotides regulate the phosphorylation of specific neuronal proteins in rat cerebral cortex slices. Proc. Natl. Acad. Sci. USA 75: 51955199.

Fowler, V., and L. Taylor (1980) Spectrin plus band 4.1 cross-link actin. J. Cell Biol. 85: 361-376.

Garner, J. A., and R. J. Lasek (1981) Clathrin is axonally transported as part of slow component b: The microfilament complex. J. Cell Biol. 88: $172-178$.

Giolli, R. A., and M. D. Guthrie (1969) The primary optic projections in the rabbit. An experimental degeneration study. J. Comp. Neurol. 136: 99-126.

Glenney, J. R., Jr., P. Glenney, and K. Weber (1982) Erythroid spectrin, brain fodrin, and intestinal brush border proteins (TW-260/240) are related molecules containing a common calmodulin-binding subunit bound to a variant cell type-specific subunit. Proc. Natl. Acad. Sci. USA 79: 4002-4005.

Goldberg, D. J., J. H. Schwartz, and A. S. Sherbany (1978) Kinetic properties of normal and perturbed axonal transport of serotonin in a single identified axon. J. Physiol. (Lond.) 281: 559-579.

Goldenring, J. R., R. S. Lasher, M. L. Vallano, T. Ueda, S. Naito, N. H. Sternberger, L. A. Sternberger, and R. J. DeLorenzo (1986) Association of synapsin I with neuronal cytoskeleton. Identification in cytoskeletal preparation in vitro and immunocytochemical localization in brain of synapsin I. J. Biol. Chem. 261: 8495-8504.

Goldstein, M. E., L. A. Stcrnbergcr, and N. H. Stcrnberger (1983) Microheterogeneity ("neurotypy") of neurofilament proteins. Proc. Natl. Acad. Sci. USA 80: 3101-3105.

Goodman, S. R. (1986) The neural cell spectrin skeleton: A review. Am. J. Physiol. 250: C347-C360.

Goodman, S. R., I. S. Zagon, and R. R. Kulikowski (1981) Identification of a spectrin-like protein in nonerythroid cells. Proc. Natl. Acad. Sci. USA 78: 7570-7574.

Grafstein, B., and D. S. Forman (1980) Intracellular transport in neurons. Physiol. Rev. 60:1167-1283.

Gumbiner, B., and R. B. Kelly (1982) Two distinct intracellular pathways transport secretory and membrane glycoproteins to the surface of pituitary tumor cells. Cell 28: 51-59.

Hirokawa, H., R. E. Cheney, and M. Willard (1983) Location of a protein of the fodrin-spectrin-TW $260 / 240$ family in the mouse intestinal brush border. Cell 32: 953-965.

Hoffman, P. F., and R. J. Lasek (1975) The slow component of axonal transport. Identification of major structural polypeptides of the axon and their generality among mammalian neurons. J. Cell Biol. 66: 351-366.

Huttner, W. B., and P. Greengard (1979) Multiple phosphorylation sites in protein I and their differential regulation by cyclic AMP and calcium. Proc. Natl. Acad. Sci. USA 76: 5402-5406.

Huttner, W. B., L. J. DeGennaro, and P. Greengard (1981) Differential phosphorylation of multiple sites in purified protein I by cyclic AMPdependent and calcium-dependent protein kinases. J. Biol. Chem. 256: $1482-1488$.

Huttner, W. B., W. Schiebler, P. Greengard, and P. DeCamilli (1983) Synapsin I (protein I), a nerve terminal-specific phosphoprotein. III. Its association with synaptic vesicles studied in a highly purified synaptic vesicle preparation. J. Cell Biol. 96: 1374-1388.

Koenig, E. S., E. Kinsman, E. A. Repasky, and L. Sultz (1985) Rapid mobility of motile varicosities and inclusions containing a-spectrin, actin, and calmodulin in regenerating axons in vitro. J. Neurosci. 5 . 715-729.

Krebs, K. E., A. C. Nairn, M. Bahler, W. Schiebler, I. S. Zagon, P. Greengard, and S. R. Goodman (1986a) The relationship of eryth- rocyte protein 4.1 to the neuron-specific phosphoprotein synapsin I. J. Cell Biol. 103(2): 542a.

Krebs, K. E., I. S. Zagon, and S. R. Goodman (1986b) Synapsin I stimulates the spectrin $(240 / 235) / F$-actin interaction in a phosphorylation-dependent manner. J. Cell Biol. 103(2): 292a.

Krebs, K. E., I. S. Zagon, and S. R. Goodman (1986c) Amelin, a brain protein immunologically related to erythrocyte protein 4.1 . J. Cell Biol. 103: 543a.

Krueger, B. K., J. Forn, and P. Greengard (1977) Depolarizationinduced phosphorylation of specific proteins, mediated by calcium ion influx, in rat brain synaptosomes. J. Biol. Chem. 252: 2764-2773.

Laemmli, U. K. (1970) Cleavage of structural protein during the assembly of the head of bacteriophage T4. Nature 227: 680-685.

Laskey, R. A., and A. D. Mills (1975) Quantitative film detection of ${ }^{3} \mathrm{H}$ and ${ }^{14} \mathrm{C}$ on polyacrylamide gels by fluorography. Eur. J. Biochem. 56: $335-341$

Lazarides, E., and W. J. Nelson (1983) Erythrocyte and brain forms of spectrin in cerebellum: Distinct membrane-cytoskeletal domains in neurons. Science 220: 1295-1296.

Levine, J., and M. Willard (1980) The composition and organization of axonally transported proteins in the retinal ganglion cells of the guinea pig. Brain Res. 194: 137-154.

Levine, J., and M. Willard (1981) Fodrin: Axonally transported polypeptides associated with the internal periphery of many cells. J. Cell Biol. 90: 631-643.

Levine, J., and M. Willard (1983) Redistribution of fodrin (a component of the cortical cytoplasm) accompanying capping of cell surface molecules. Proc. Natl. Acad. Sci. USA 80: 191-195.

Levine, J., C. Simon, and M. Willard (1982) Mechanistic implications of the behavior of axonally transported proteins. In Axoplasmic Transport, D. G. Weiss, ed., pp. 275-278, Springer-Verlag, Berlin.

Llinas, R., T. L. McGuinness, C. S. Leonard, M. Sugimori, and P. Greengard (1985) Intraterminal injection of synapsin I or calciumcalmodulin-dependent protein kinase II alters neurotransmitter release at the squid giant synapse. Proc. Natl. Acad. Sci. USA 82:30353039.

Lorenz, T., and M. Willard (1978) Subcellular distribution of intraaxonally transportcd polypeptides in the rabbit visual systcm. Proc. Natl. Acad. Sci. USA 75: 505-509.

McCaffery, C. A., and L. J. DeGennaro (1986) Determination and analysis of the primary structure of the nerve-terminal specific phosphoprotein, synapsin-I. EMBO J. 5: 3167-3173.

Naito, S., and T. Ueda (1981) Affinity-purified anti-protein I antibody: Specific inhibitor of phosphorylation of protein $\mathrm{I}$, a synaptic protein. J. Biol. Chem. 256: 10657-10663.

Navone, F., P. Greengard, and P. De Camilli (1984) Synapsin I in nerve terminals: Selective association with small synaptic vesicles. Science 226: 1209-1211.

Nestler, E., and P. Greengard (1982a) Nerve impulses increase the phosphorylation state of protein I in rabbit superior cervical ganglion. Nature 296: 452-454.

Nestler, E., and P. Greengard (1982b) Distribution of protein I and regulation of its state of phosphorylation in the rabbit superior cervical ganglion. J. Neurosci. 2: 1011-1023.

O'Farrell, P. H. (1975) High resolution two-dimensional electrophoresis of proteins. J. Biol. Chem, 250: 4007-4021.

O'Farrell, P. Z., H. M. Goodman, and P. H. O'Farrell (1977) Highresolution two-dimensional electrophoresis of basic as well as acidic proteins. Cell 12: 1133-1142.

Repasky, E. A., B. L. Granger, and E. Lazarides (1982) Widespread occurrence of avian spectrin in nonerythroid cells. Cell 29:821-833.

Schiebler, W., R. Jahn, J.-P. Doucet, J. Rothlein, and P. Greengard (1986) Characterization of synapsin I binding to small synaptic vesicles. J. Biol. Chem. 261: 8383-8390.

Sorensen, R. G., and J. A. Babitch (1984) Identification and comparison of protein $I$ in chick and rat forebrain. J. Neurochem. 42: 705710.

Specht, S. C., and K. J.Sweadner (1984) Two different Na,K-ATPases in the optic nerve: Cells of origin and axonal transport. Proc. Natl. Acad. Sci. USA 81: 1234-1238.

Sternberger, L. A., and N. H. Sternberger (1983) Monoclonal antibodies distinguish phosphorylated and nonphosphorylated forms of neurofilaments in situ. Proc. Natl. Acad. Sci. USA 80: 6126-6130.

Strombom, U., J. Forn, A. C. Dolphin, and P. Greengard (1979) Reg- 
ulation of the state of phosphorylation of specific neuronal proteins in mouse brain by in vivo administration of anesthetic and convulsant agents. Proc. Natl. Acad. Sci. USA 76: 4687-4690.

Tartakoff, A., and P. Vassalli (1978) Comparative studies of intracellular transport of secretory proteins. J. Cell Biol. 79: 699-707.

Tsou, K., and P. Greengard (1982) Regulation of phosphorylation of proteins I, IIIa, and IIIb in rat neurohypophysis in vitro by electrical stimulation and by neuroactive agents. Proc. Natl. Acad. Sci. USA 79: 6075-6079.

Ueda, T., and P. Greengard (1977) Adenosine 3':5'-monophosphateregulated phosphoprotein system of neuronal membranes. I. Solubilization, purification, and some properties of an endogenous phosphoprotein. J. Biol. Chem. 252: 5155-5163.

Ueda, T., H. Maeno, and P. Greengard (1973) Regulation of endogenous phosphorylation of specific proteins in synaptic membrane fractions from rat brain by adenosine $3^{\prime}: 5^{\prime}$-monophosphate. J. Biol. Chem. 248: 8295-8305.

Ungewickell, E., P. M. Bennett, R. Calvert, V. Ohanian, and W. B Gratzer (1979) In vitro formation of a complex between cytoskeletal proteins of the human erythrocyte. Nature 280: 811-814.

Vale, R. D., T. S. Reese, and M. P. Sheetz (1985) Identification of a novel force generating protein (kinesin) involved in microtubule-based motility. Cell 41: 39-50.

Willard, M. (1977) The identification of two intra-axonally transported polypeptides resembling myosin in some respects in the rabbit visual system. J. Cell Biol. 75: 1-11.

Willard, M. B. (1984) Techniques for studying axonally transported proteins. In Current Methods in Cellular Neurobiology, vol. 2, J. L. Barker and J. F. McKelvy, eds., pp. 35-84, Wiley, New York.

Willard, M. B., and K. L. Hulebak (1977) The intra-axonal transport of polypeptide $\mathrm{H}$ : Evidence for a fifth (very slow) group of transported proteins in the retinal ganglion cells of the rabbit. Brain Res. 136: 289-306.

Willard, M., W. M. Cowan, and P. R. Vagelos (1974) The polypeptide composition of intra-axonally transported proteins: evidence for four transport velocities. Proc. Natl. Acad. Sci. USA 71: 2183-2187.

Willard, M., M. Wiseman, J. Levine, and P. Skene (1979) Axonal transport of actin in rabbit retinal ganglion cells. J. Cell Biol. 81: 581591.

Zagon, I. S., P. J. McLaughlin, and S. R. Goodman (1984) Localization of spectrin in mammalian brain. J. Neurosci. 4: 3089-3100. 